Resona Jumal Ilmiah Pengabdian Masyarakat Vol. 1, No. 1 (2017) 26-33

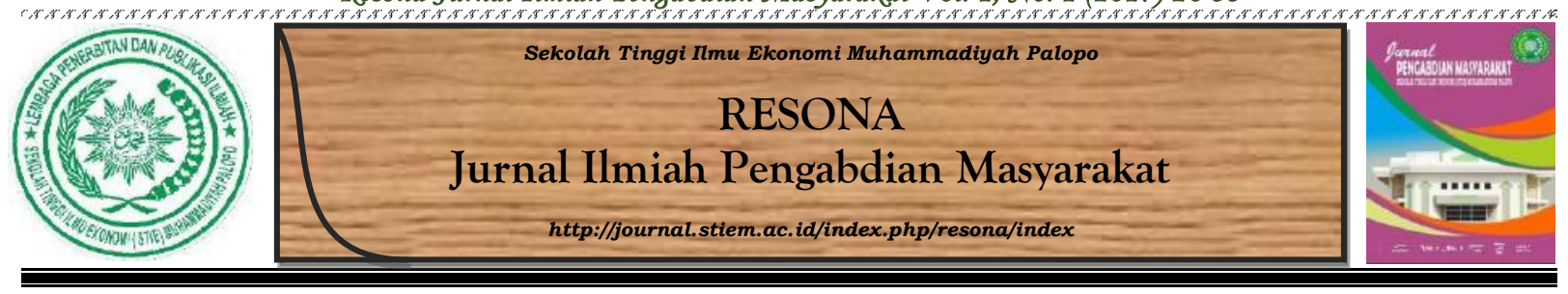

\title{
Pengolahan Ikan Bandeng (Chanos-Chanos) Cabut Duri
}

Andi Dahri Adi Patra Ls

$\underline{\underline{\text { Sekolah Tinggi Ilmu Ekonomi Muhammadiyah Palopo }}}$

\section{INFO NASKAH

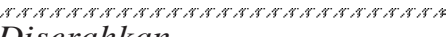 \\ iserahkan \\ 14 Desember 2017 \\ Diterima dan disetujui \\ 26 Desember 2017

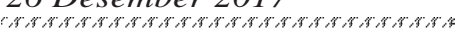

\section{Kata Kunci:}

Ikan Bandeng

Milkfish

Chanos-chanos

Cabut duri

\begin{abstract}
ABSTRAK Tujuan pengabdian ini adalah memberikan solusi kepada kelompok mitra pengusaha mikro bandeng cabut duri terhadap produksi dan aspek manajemen usaha ikan bandeng cabut duri di kota Palopo. Permasalahan mitra cukup kompleks. Jumlah pelaku usaha relatif terbatas, sedangkan jumlah permintaan cukup besar menunjukkan terdapat permasalahan dan kendala pengusaha (pelaku) produksi Ikan bandeng Tanpa Duri masuk ke industri. Masalah dan kendala awal yaitu penguasaan teknik mencabut duri, yang memang membutuhkan teknik khusus. Kendala dalam pemasaran yang dirasakan yaitu pasokan Bandeng segar yang bersifat musiman, sehingga mengakibatkan adanya kemungkinan tidak dapat memenuhi permintaan yang ada (stock out). Kendala lainnya adalah daya tahan bandeng tanpa duri yang terbatas akibat penggunaan teknologi pengemasan manual (tanpa mesin vakum). Ikan Bandeng Tanpa Duri ini $100 \%$ tanpa bahan pengawet, hanya bertahan dua hari dalam kondisi dingin (bukan beku), dan enam bulan dalam kondisi beku. Pemberdayaan Kuliah Kerja Nyata Pembelajaran Pengabdian Masyarakat (KKN-PPM) yang akan diimplementasikan adalah metode SLA (the sustainable livelihood approach). Target luaran dari dari KKN-PPM ini adalah ketersediaan tenaga terampil di bidang teknis pengolah ikan bandeng cabut duri, pendapatan mitra meningkat signifikan, ikan bandeng tanpa duri lebih awet, dan waktu penyelesaian proses produksi lebih efisien.
\end{abstract}

\section{Pendahuluan}

Penanggulangan kemiskinan dilakukan melalui berbagai upaya untuk menjamin kehormatan; perlindungan dan pemenuhan hak-hak dasar masyarakat miskin; perwujudan keadilan dan kesetaraan gender; serta percepatan pembangunan pedesaan, perkotaan, kawasan pesisir, dan kawasan tertinggal. Masalah kemiskinan bukan hanya diukur dari pendapatan, tetapi juga masalah kerentanan dan kerawanan orang atau sekelompok orang baik laki-laki maupun perempuan untuk menjadi miskin. Masalah kemiskinan juga menyangkut tidak 
terpenuhinya hak-hak dasar masyarakat miskin untuk mempertahankan dan mengembangkan kehidupan yang bermartabat (Depsos RI, 2013).

Secara konseptual, pemberdayaan masyarakat adalah upaya untuk meningkatkan harkat dan martabat lapisan masyarakat yang dalam kondisi sekarang tidak mampu untuk melepaskan diri dari perangkap kemiskinan dan keterbelakangan. Dengan kata lain memberdayakan adalah memampukan dan memandirikan masyarakat. Pemberdayaan masyarakat menyangkut dua kelompok yang saling terkait, yaitu masyarakat yang belum berkembang sebagai pihak yang harus diberdayakan, dan pihak yang menaruh kepedulian sebagai pihak yang memberdayakan. Pemberdayaan masyarakat mengandung arti mengembangkan kondisi dan situasi sedemikian rupa sehingga masyarakat memiliki daya dan kesempatan untuk mengembangkan kehidupannya.

Potensi perikanan dan kelautan di Kota Palopo didukung letak strategis Kota Palopo pada garis pantai Sulawesi Selatan dan menghadap ke Teluk Bone berdampak langsung pada daerah ini, yaitu memiliki potensi ekonomi yang cukup besar di sektor perikanan. Palopo memiliki potensi perairan dengan 295 jenis ikan karang dan berbagai jenis ikan konsumsi yang bernilai ekonomis tinggi. Profil mitra usaha dalam pengusulan pengabdian Kuliah Kerja Nyata-Pembelajaran Pemberdayaan Masyarakat (KKN-PPM) ini adalah kelompok pengusaha mikro Poklahsar TB'7 di kelurahan To’bulung Kecamatan Bara Poklahsar TB'7 yang sudah aktif produksi Ikan Bandeng Cabut Duri sebagai mitra I yang dipimpin oleh Bapak Rahman dan Kelompok Lestari Nusantara Jaya (LNJ) yang beralamat di Kelurahan Ponjalae, Kecamatan Wara Timur, Kota Palopo dipimpin oleh Bapak Muhammad Sandi.

Ikan bandeng (Latin: chanoschanos atau Inggris: milkfish) merupakan salah satu jenis ikan yang memiliki rasa spesifik dan telah dikenal di Indonesia bahkan di luar negeri. Menurut penelitian Balai Pengembangan dan Penelitian Mutu Perikanan (1996), kandungan omega-3 bandeng sebesar 14.2\% melebihi kandungan omega-3 pada ikan salmon (2.6\%), ikan tuna (0.2\%) dan ikan sardines/mackerel (3.9\%). Pengolahan bandeng tanpa duri merupakan salah satu proses pengolahan diversifikasi produk perikanan, terutama produk perikanan dari bahan baku ikan bandeng. Jumlah produksi bandeng tanpa duri segar yang diproduksi per hari oleh mitra masih berkisar 10-20 per $\mathrm{kg}$. Total produksi ini, $70-80 \%$ atau berkisar $7-16 \mathrm{~kg}$ merupakan produk bandeng tanpa duri segar yang dibekukan (fresh frozen) dan sisanya merupakan produk bandeng tanpa duri olahan seperti bandeng asap tanpa duri, bandeng goreng. Bandeng tanpa duri memiliki karakteristik proses produksi yang relatif sulit bagi 
pemula (meskipun setelah mahir, proses ini menjadi sederhana) serta membutuhkan ketekunan serta ketelitian tinggi, khususnya pada saat mencabut duri bandeng tersebut. Seseorang yang telah mahir membutuhkan waktu 3-4 menit untuk melakukan pencabutan tulang dan duri bandeng. Tetapi bila belum mahir maka bisa mengerjakannya dalam waktu 15-20 menit untuk setiap ekor bandeng.

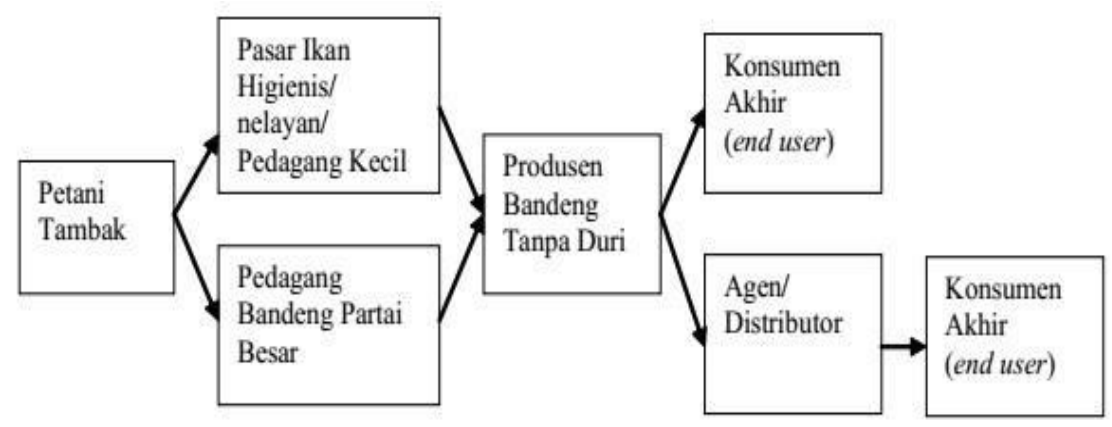

Usaha produksi ikan bandeng tanpa duri memiliki prospek sangat cerah dan dapat terus dikembangkan. Hal ini didukung dengan beberapa aspek berikut: (a) potensi bahan baku ikan bandeng segar cukup besar dan melimpah; (b) bandeng umumnya sudah dikenal dan disukai oleh masyarakat baik di perkotaan maupun di pedesaan; (c) teknologi dan peralatan pengolahan bandeng tanpa duri relatif sederhana sehingga tidak membutuhkan investasi yang besar; dan (d) memiliki nilai tambah yang cukup besar jika dibandingkan dengan nilai jual hanya dalam bentuk bandeng segar dengan duri. Peluang pasar untuk produk bandeng tanpa duri ini sangat besar, karena didukung adanya peningkatan permintaan yang cukup besar untuk produk ikan bandeng. Kesadaran masyarakat akan pentingnya mengkonsumsi ikan juga mendorong peningkatan permintaan ikan. Potensi pasar yang relatif besar menjadi daya tarik masuknya produsen baru dalam industri produksi bandeng tanpa duri ini.

Permasalahan yang dihadapi oleh mitra dan disepakati dengan tim pengabdian masyarakat untuk diselesaikan, antara lain: (a) keterbatasan pengetahuan dan penguasaan teknik mencabut duri, selama ini hanya berbekal pengetahuan otodidak dan belum pernah mengikuti pelatihan tenaga terampil atau dibimbing oleh profesional; (b) pasokan bandeng segar yang bersifat musiman, sehingga mengakibatkan adanya kemungkinan tidak dapat memenuhi permintaan yang ada (stock out); (c) daya tahan bandeng tanpa duri yang terbatas dengan pengemasan yang masih manual hanya bertahan 2 hari dalam kondisi dingin tanpa dibekukan, dan 6 bulan dalam kondisi dibekukan namun dengan proses kemasan vakum bertahan 1 bulan dalam kondisi dingin tanpa dibekukan; (d) Alat produksi masih tergolong 
tradisional dan terbatasnya sarana prasarana pendukung produksi; dan (e) tidak memiliki keterampilan pengelolaan keuangan sehingga tidak adanya pencatatan/administrasi tentang segala sesuatu pengeluaran dan pemasukan dari usaha.

\section{Metode Pelaksanaan}

Pelaksanaan program pembinaan (pelatihan dan pendampingan) terdiri dari beberapa tahapan dengan tujuan yang diharapkan. Adapun tahapan-tahapannya adalah:

a. Persiapan dan Pembekalan

Persiapan dan pembekalan melibatkan Pusat Penelitian dan Pengabdian kepada Masyarakat (P3M) STIE Muhammadiyah Palopo dan seluruh peserta dalam program KKN-PPM sebelum diterjunkan pada lokasi KKN-PPM. Mekanisme pelaksanaan kegiatan pemberdayaan masyarakat terhadap pengolahan ikan bandeng tanpa duri ini dengan materi pembekalan dan keterampilam dalam melakukan penatalaksanaan ikan bandeng tanpa duri yang perlu diberikan kepada mahasiswa.

\section{b. Pelaksanaan Program}

Berdasarkan hasil observasi dilapangan, maka perencanaan pelaksanaan program dilakukan dengan langkah sebagai berikut: (a) serah mahasiswa KKN-PPM ke pejabat daerah setempat (Camat Wara Timur, beserta unsur muspida, Lurah Pontap beserta jajarannya) sebagai tanda resmi KKN-PPM dimulai; (b) sosialisasi dilaksanakan oleh mahasiswa beserta aparat kelurahan setempat dibantu unsur pemuda/karang taruna; (c) rencana program kerja dan aktivitas mahasiswa di bagi sedemikian rupa sesuai tupoksi dan peran dalam usaha pengolahan ikan bandeng tanpa duri; (d) penatalaksanaan pengolahan ikan bandeng cabut duri; dan (e) pembelajaran kelompok disertai praktik, teknik pencabutan duri ikan bandeng, sanitasi dan kebersihan, teknik pembuatan dan pengemasan yang baik, dan manajemen pasca produksi (pemasaran). Pembelajaran disertai praktik dilakukan oleh mahasiswa bersama-sama dengan kelompok masyarakat pengrajin olahan ikan bandeng cabut duri.

\section{c. Evaluasi dan Monitoring}

Kegiatan evaluasi dan monitoring dilakukan secara menyeluruh mulai dari saat pembekalan mahasiswa sampai pada saat berakhirnya kegiatan. Sebelum dilakukan pelatihan dan praktikum penatalaksanaan usaha pengolahan bandeng cabut duri, dilakukan penelusuran 
dan survei informasi mengenai kebutuhan mahasiswa KKN-PPM terkait dengan topik pengolahan ikan bandeng cabut duri dengan peningkatan pengetahuan dan keterampilan dalam bidang usaha pengolahan ikan bandeng cabut duri.

Tabel 1. Skema dan Rencana Pemecahan Masalah

\begin{tabular}{|l|l|l|}
\hline \multicolumn{1}{|c|}{ Permasalahan } & \multicolumn{1}{|c|}{ Akar Masalah } & $\begin{array}{c}\text { Metode Pendekatan yang ditawarkan } \\
\text { untuk }\end{array}$ \\
\hline \multicolumn{2}{|c|}{$\begin{array}{c}\text { Aspek Produksi } \\
\text { Pemecahan masalah }\end{array}$} \\
\hline $\begin{array}{l}\text { Kemampuan } \\
\text { produksi } \\
\text { terbatas }\end{array}$ & $\begin{array}{l}\text { Tenaga kerja terampil yang } \\
\text { menguasai teknik Cabut Duri } \\
\text { Ikan bandeng terbatas }\end{array}$ & $\begin{array}{l}\text { Pelatihan dan workshop keterampilan } \\
\text { teknis Cabut duri untuk meciptakan } \\
\text { tenaga terampil baru. }\end{array}$ \\
\hline $\begin{array}{l}\text { Harga produk } \\
\text { bervariasi }\end{array}$ & $\begin{array}{l}\text { Pasokan Ikan Bandeng Segar } \\
\text { yang bersifat musiman }\end{array}$ & $\begin{array}{l}\text { Pelatihan tentang praktis manajemen } \\
\text { persediaan (inventory manajemen } \\
\text { berbasis ABC) mengatasi pasokan bahan } \\
\text { baku Ikan segar yang musiman, } \\
\text { penyebab harga produk bervariasi }\end{array}$ \\
\hline $\begin{array}{l}\text { Daya tahan ikan } \\
\text { Bandeng tanpa } \\
\text { Duri terbatas }\end{array}$ & $\begin{array}{l}\text { Pengemasan dan kemasan } \\
\text { masih manual }\end{array}$ & $\begin{array}{l}\text { Introduksi teknologi pengemasan dengan } \\
\text { mesin vacuum sealer }\end{array}$ \\
\hline $\begin{array}{l}\text { Pemborosan } \\
\text { waktu dan tenaga }\end{array}$ & $\begin{array}{l}\text { Peralatan yang digunakan } \\
\text { masih tradisional }\end{array}$ & $\begin{array}{l}\text { Pembaharuan alat-alat produksi untuk } \\
\text { efisiensi dan efektifitas }\end{array}$ \\
\hline \multicolumn{2}{|c|}{ Aspek Manajemen } \\
\hline $\begin{array}{l}\text { Arus kas dan } \\
\text { modal tidak jelas }\end{array}$ & $\begin{array}{l}\text { Tidak memiliki keahlian } \\
\text { dalam pengelolaan keuangan } \\
\text { dan manajemen usaha }\end{array}$ & $\begin{array}{l}\text { Pelatihan keuangan dan administrasi } \\
\text { usaha }\end{array}$ \\
\hline
\end{tabular}

\section{Hasil dan Pembahasan}

Terjadi peningkatan keterampilan mahasiswa sebagai sasaran antara yang strategis dalam untuk mempersiapkan tenaga teknik yang terampil di bidang usaha pencabutan bandeng tanpa duri. Adanya keterlibatan langsung dari mahasiswa KKN STIE Muhammadiyah Palopo 2016 dalam workshop peningkatan keterampilan bandeng cabut duri dalam usaha peningkatan bandeng cabut duri di Kelurahan Pontap, Kecamatan Wara Timur, melalui workshop dan pendampingan proses produksi.

a. Terbangunnya jaringan kerja dalam kelompok produksi usaha kecil bandeng cabut duri dan membuka akses pemasaran melalui kemitraan dengan pengusaha langsung bandeng cabut duri dalam mengimplementasikan pengabdian masyarakat sesuai tuntutan kurikulum yang berlaku pada mata kuliah KKN-PPM dengan bobot 4 sks.

b. Efisiensi waktu penyelesaian pada proses produksi per orang lebih efisien dari $12 \mathrm{~kg}$ per hari yang dicabut durinya, dengan perbaikan dan pembaharuan alat menjadi $18 \mathrm{~kg}$ ikan per orang dalam satu hari 
c. Implementasi penggunaan introduksi peralatan dan bahan dalam praktik bandeng cabut duri realistic untuk para pelaku usaha bandeng cabut duri oleh mahasiswa KKN-PPM sehingga pihak pengusaha dapat memanfaatkan sarana dan produk yang dihasilkan secara komersil.

d. Ketersediaan produk jadi di luar musim terjaga karena stok produksi di saat musim menutupi permintaan di luar musim panen ikan segar.

e. Terlihatnya pola pemberdayaan kolaboratif antara perguruan tinggi dan nelayan pelaku usaha bandeng cabut duri di Kota Palopo melalui pendampingan dalam transfer keterampilan, modal, dan akses pemasaran yang lebih luas.

f. Pengalaman belajar yang nyata dalam pemberdayaan masyarakat yang berharga bagi mahasiswa dengan adanya keterlibatan dalam masyarakat secara langsung menemukan, merumuskan, memecahkan persoalan, dan menanggulangi permasalahan pembangunan secara pragmatis interdisipliner.

Sosialisasi kegiatan KKN-PPM Sekolah Tinggi Ilmu Ekonomi Muhammadiyah Palopo dilakukan pada seminar program kegiatan KKN-PPM yang dilaksanakan di kantor kelurahan dengan mengundang segenap unsur Muspida kecamatan Wara Timur dan jajaran Muspida Kelurahan Pontap dengan dihadiri langsung oleh Bapak Camat dan Ibu Lurah kelurahan Pontap, tokoh masyarakat, Tim Pengabdi dan Mahasiswa peserta KKN-PPM yang diterjunkan untuk mebawa topik KKN-PPM Pengolahan Ikan bandeng Cabut Duri. Pada sosialisasi ini dijelaskan rancangan program kerja KKN-PPM dengan target dan luaran yang hendak dicapai selama Pembelajaran dan Pemberdayaan masyaarakat berlangsung.

\section{Pelatihan Mahasiswa dalam Usaha Pengolahan Bandeng Cabut Duri}

Pelatihan yang merupakan tindak lanjut dari rencana dalam seminar program kerja melibatkan seluruh stakehoders dalam kegiatan KKN-PPM pengolahan bandeng (chanoschanos) cabut duri yang terdiri dari pelaku usaha pengolahan Ikan 14 orang, mahasiswa 22 orang, tim pengusul pengabdian 2 orang, Ketua P3M dan Sekretaris, masyarakat umum dan dihadiri langsung oleh tim dari Dinas Kelautan dan Perikanan Kota Palopo 8 orang, sekaligus dengan pemateri dan tenaga ahli di bidang bandeng cabut duri. Materi yang dilatihkan mencakup tinjauan mengenai permasalahan, peluang dan tantangan dalam usaha pengolahan produk ikan secara teori dan praktik penatalaksanaan bandeng cabut duri, analisis usaha, dan pascaproduksi. Pelaksanaan pelatihan menggunakan sistem pembelajaran terbuka yang 
memungkinkan peserta untuk bereksplorasi dan berimprovisasi sesuai dengan kreatifitas dan keahliannya sendiri dalam mengolah bahan yang tersedia

Hasil yang di capai pada kegiatan ini adalah mampu melakukan perencanaan usaha, teknis usaha, manajemen usaha serta manajemen pascaproduksi yang di perlukan dalam usaha bandeng cabut duri untuk meningkatkan keterampilan di bidang kewirausahaan mahasiswa sebagai bekal intelektual muda ekonomi dan sekaligus bekal untuk terjun di masyarakat setelah menyelesaikan studi di Sekolah Tinggi Ilmu Ekonomi Muhammadiyah Palopo.

\section{Proses Pelatihan dan Praktikum dalam Pengolahan Ikan Bandeng Cabut Duri}

Selain pelatihan materi yang dilaksanakan untuk membekali pelaku usaha pengolahan bandeng cabut duri, mahasiswa juga mengikuti pelatihan dalam bentuk praktikum penatalaksanaan pencabutan ikan bandeng sebagai produk utama dalam usaha pengolahan bandeng cabut duri. Pelatihan juga disertai dengan materi tentang manajemen usaha dan pemasaran produk sehingga nantinya selain skill memproduksi ikan bandeng cabut duri, peserta juga memiliki soft skill dalam bidang manajemen dan kewirausahaan. Hasil yang dicapai pada kegiatan pelatihan dan praktikum penatalaksanaan bandeng cabut duri adalah memperoleh pemahaman baru mengenai teknik pengolahan bandeng cabut duri dan mampu untuk melakukan sendiri sehingga persoalan mengenai tenaga terampil yang dibutuhkan untuk menopang usaha pengolahan ikan bandenng cabut duri dapat ditingkatkan dengan penyebaran pengetahuan yang diperoleh oleh mahasiswa.

\section{Simpulan dan Saran}

Pendekatan pemberdayaan pada intinya memberikan tekanan pada otonomi pengambilan keputusan dari suatu kelompok masyarakat yang berlandaskan pada sumber daya pribadi, langsung (melalui partisipasi) demokratis dan pembelajaran sosial melalui pengalaman langsung. Pemberdayaan masyarakat mengandung arti mengembangkan kondisi dan situasi sedemikian rupa sehingga masyarakat memiliki daya dan kesempatan untuk mengembangkan kehidupannya. Sebaiknya masyarakat harus terlibat dalam proses tersebut sehingga mereka dapat lebih memperhatikan hidupnya untuk memperoleh rasa percaya diri, memiliki harga diri dan pengetahuan untuk mengembangkan keahlian baru. Prosesnya dilakukan secara kumulatif sehingga semakin banyak keterampilan yang dimiliki seseorang, semakin baik kemampuan berpartisipasinya. Kegiatan KKN-PPM ini telah menghasilkan, jaminan Ketersediaan produk jadi di luar musim terjaga karena stok produksi di saat musim menutupi permintaan di luar 
musim panen ikan segar; produk lebih hiegienis karena kemasan kedap udara; ikan bandeng segar tanpa duri bertahan 1 bulan yang sebelumnya hanya 2 hari pada kondisi dingin dan bertahan 6 bulan dalam kondisi beku.

Pemerintah sebagai agen perubahan dapat menerapkan kebijakan pemberdayaan masyarakat dengan tiga arah tujuan, yaitu enabling, empowering, dan protecting. Enabling maksudnya menciptakan suasana atau iklim yang memungkinkan potensi masyarakat untuk berkembang. Sedangkan empowering, bertujuan untuk memperkuat potensi atau daya yang dimiliki oleh rakyat dengan menerapkan langkah-langkah nyata, yakni dengan menampung berbagai masukan dan menyediakan prasarana dan sarana yang diperlukan. Protecting, artinya melindungi dan membela kepentingan masyarakat lemah.

\section{Daftar Pustaka}

Budiharjo, A. 2009. Strategi Peningkatan Daya Tarik Pasar Produk Olahan Ikan Bandeng Presto Sebagai Komoditas Oleh-Oleh Khas Semarang. Jurnal Pena Akuatika, 1 (1): 69-75

Data Harga jual Ikan di Indonesia tahun 2012. http://www.pdn.kkp.go.id.

Depsos RI. 2013. Kebijakan Komite Penanggulangan Kemiskinan Kaitannya dengan Prospek PKAT.http://www.depsos.go.id/modules.php?name=News\&file=article\&sid=597.

Senjaya, K., dan R.H. Mustamu. 2013. Pengelolaan dan Pengembangan Usaha pada Perusahaan Pengolahan Ikan Bandeng di Sidoarjo. Jurnal Agora, 1 (1).

Rangka, N.A. dan A.I.J. Assad. 2010. Teknologi Budidaya Ikan Bandeng, Prosiding Teknologi Akuakultur, 187-203.

Bank Indonseia. 2007. Pola Pembiayaan Usaha Mikro Kecil dan Menengah, Bandeng Asap. 